\title{
МУНІЦИПАЛЬНЕ ЗАМОВЛЕННЯ ЯК МЕХАНІЗМ РЕФОРМУВАННЯ ОХОРОНИ ЗДОРОВ'Я МІСТА ТЕРНОПОЛЯ ЗА УМОВ ДЕЦЕНТРАЛІЗАЦІї
}

\author{
${ }^{1}$ ДВНЗ «Тернопільський державний медичний університет \\ імені І. Я. Горбачевського МОЗ України», м. Тернопіль, Україна \\ 2Тернопільська міська рада, м. Тернопіль, Україна
}

\begin{abstract}
Мета: розглянути механізм муніципального замовлення медичної галузі міста Тернополя за умов децентралізації та ресормування системи охорони здоров'я.

Матеріали і методи. Матеріалами дослідження є принципи фрінансування системи охорони здоров'я міста Тернополя та робота місцевих медичних закладів, а методами - опис, аналіз, синтез, узагальнення, графічний дизайн.

Результати. Протягом останніх років за умов децентралізації на місцеву владу покладено важливе завдання створення максимальних можливостей надавати якісні та доступні послуги, не збільшуючи при цьому податкового навантаження на людей. щорічно бюджет медичної галузі міста Тернополя стикається з проблемою недофінансування з державного бюджету. Лише в 2018 р. дефріцит бюджету на заробітну плату становив майже 50 млн грн. Тому Тернопільська міська рада власними коштами компенсує цю різницю. У 2018 р. дофрінансування 3 міського бюджету становить 65 млн 377 тис. грн або 24,3 \% всього фрінансування медицини. В 2019 р. у галузь охорони здоров'я міста закладено 84,6 млн грн або 33,6 \% від загального бюджету. Також встановлено, що бюджет медицини в 2018 р. - соціально спрямований. Основний акцент зроблений на видачу безкоштовних рецептів, зубопротезування пільгових категорій громадян, медичну допомогу учасникам АТО, чорнобильцям. Охорона здоров'я - пріоритет діяльності Тернопільської міської ради. Тому кошти з міського бюджету виділяють не тільки на соціальну складову, але й на проведення капітальних ремонтів, реконструкцій, закуплення нового обладнання. Також завдяки фінансам, виділеним із міського бюджету, вперше за багато років немає дефріциту коштів на заробітну плату.

Висновки. Спостерігаємо чітку позитивну тенденцію фрінансування медичної галузі міста з міського бюджету, на що вказують відсутність заборгованості із заробітної плати працівникам закладів охорони здоров'я, модернізація медичних установ та оснащення їх сучасним обладнанням, підвищення тривалості життя тернополян, позитивний природний приріст.
\end{abstract}

КЛЮчОВІ СЛОВА: медицина; здоров'я; фрінансування; бюджет; децентралізація.

Протягом останніх років за умов децентралізації на місцеву владу покладено надзвичайно важливе завдання - створення максимальних можливостей надавати якісні та доступні послуги на місцях, не збільшуючи при цьому податкового навантаження на людей [6]. У дію вступає один із найважливіших регуляторів економічних процесів на місцевому рівні - система муніципального замовлення, яка ґрунтується на розподілі фрінансових ресурсів за адміністративно-територіальними ланками [10]. Тому актуальним стає питання пошуку та впровадження ефрективного розподілу фрінансових ресурсів у системі охорони здоров'я, яке б дозволило закладам охорони здоров'я максимально реалізувати делеговані повноваження із надання якісної та доступної медичної допомоги населенню [5].

Метадослідження: наприкладі міста Тернополя розглянути механізм муніципального замовлення медичної галузі за сучасних умов децентралізації та реформування системи охорони здоров'я.

Матеріали і методи. Матеріалами дослідження $€$ принципи фрінансування системи охорони здоров'я міста Тернополя та робота місцевих медичних закладів за умов реформування медичної галузі, а методами - опис, аналіз, синтез, узагальнення, графрічний дизайн.

Результати дослідження та їх обговорення. 2018 р. для галузі охорони здоров'я міста Тернополя - це рік глибокої модернізації медичних закладів, структурних змін та вироблення нової практики відносин між Тернопільською міською радою та суб'єктами охорони здоров'я. Головним завданням медичної галузі $€$ реалізація делегованих державою повноважень із надання якісної та доступної медичної допомоги жителям громади за умов рефрормування галузі, нових правових та фрінансово-господарських реалій.

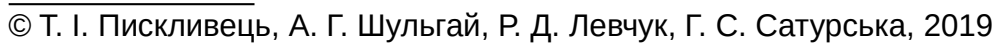


Так, у місті Тернополі мережу закладів охорони здоров'я складають 8 медичних установ, які, відповідно до Закону України «Про внесення змін до деяких законодавчих актів України щодо удосконалення законодавства 3 питань діяльності закладів охорони здоров'я» від 06.04.2017 р., автоматизовано шляхом реорганізації в комунальні некомерційні підприємства, де працює понад 3,5 тис. працівників та розгорнуто 970 ліжок [1].

На виконання делегованих повноважень фрінансування галузі відбувається за змішаним принципом: кошти державної субвенції, кошти місцевих бюджетів та віднедавна - кошти Національної служби здоров'я України [7].

Кожного року місто стикається 3 проблемою недофінансування медичної галузі з державного бюджету. Лише в 2018 р. деоріцит бюджету на заробітну плату становив майже 50 млн грн. Тому щорічно Тернопільська міська рада власними коштами дофінансовує цю різницю, у тому числі напрямки соціально значимі: забезпечення пацієнтів із цукровим діабетом інсуліном, орфанні захворювання, матеріали для догляду за людьми 3 додатковими потребами тощо. Так, бюджет галузі охорони здоров'я міста Тернополя в 2018 р. становив 269 млн 356 тис. грн, 3 яких 65 млн 377 тис. грн - це кошти місцевого бюджету, що становить 24,3 \% всього фрінансування [2]. Для порівняння, бюджет галузі в 2016 р. становив 163 млн 966,8 тис. грн, у 2017 р. - 231 млн 557,6 тис. грн, що менше від бюджету 2018 р. на 39 та 14 \% відповідно (табл. 1).

Таблиця 1. Структура фрінансування галузі охорони здоров'я міста Тернополя (тис. грн)

\begin{tabular}{|c|c|c|c|c|}
\hline \multirow{2}{*}{$\begin{array}{c}\text { Найменування } \\
\text { видатків }\end{array}$} & \multirow{2}{*}{2016 p. } & \multirow{2}{*}{2017 p. } & \multicolumn{2}{|r|}{2018 p. } \\
\hline & & & усього & $\begin{array}{c}\text { у тому числі з міського } \\
\text { бюджету }\end{array}$ \\
\hline $\begin{array}{l}\text { Виплата заробітної плати } 3 \\
\text { нарахуваннями }\end{array}$ & 122766,2 & 189614,0 & 204473,3 & 33560,6 \\
\hline Медикаменти & 8625,8 & 6658,0 & 13082,6 & 2170,0 \\
\hline Продукти харчування & 2777,6 & 2903,3 & 3205,9 & - \\
\hline $\begin{array}{l}\text { Пільгове зубопротезування } \\
\text { пенсіонерів за віком та іншими } \\
\text { пільговими категоріями }\end{array}$ & 750,0 & 950,0 & 1094,0 & - \\
\hline $\begin{array}{l}\text { Пільгове зубопротезування для } \\
\text { реабілітованих осіб }\end{array}$ & 256,6 & 400,0 & 480,7 & 480,7 \\
\hline $\begin{array}{l}\text { Пільгове зубопротезування для } \\
\text { учасників АТО }\end{array}$ & 570,0 & 823,0 & 933,1 & 933,1 \\
\hline $\begin{array}{l}\text { Оплата за постачання } \\
\text { енергоносіїв }\end{array}$ & 15218,2 & 17421,2 & 20463,6 & 20463,6 \\
\hline Інші видатки & 13829,0 & 14011,1 & 25622,8 & 7769,4 \\
\hline ВСьОГО & 163966,8 & 231557,6 & 269356,0 & 65377,4 \\
\hline
\end{tabular}

Варто також зазначити, що бюджет медицини в 2018 р. - соціально спрямований, тому основний акцент фрінансування був зроблений на соціальну складову. Це видача безкоштовних рецептів і зубопротезування для пільгових категорій громадян, медична допомога учасникам АТО, чорнобильцям тощо, що в сумі становить $11 \mathrm{mлн}$ 389,4 тис. грн (діагр. 1).

щодо 2019 р., то в міському бюджеті на галузь охорони здоров'я закладено 84,6 млн грн, що становить 33,6 \% від загального бюджету медицини міста Тернополя. Кошти першочергово направлені на заробітну плату працівникам закладів охорони здоров'я, закупівлю медикаментів, надання медичної допомоги учасникам АТО і проведення капітальних ремонтів та реконструкцій. Необхідно зазначити, що з вищеперерахованих витрат капітальні видатки та видатки на надання допомоги учасникам ATO з міського бюджету покриваються на $100 \%$ річної суми. Це говорить про щорічну вагому роль муніципального замовлення в механізмі ресрормування галузі охорони здоров'я міста Тернополя за умов децентралізації.

Разом із тим, критично важливим за умов реформи є збереження якості, доступності та рівня медичної допомоги, яка надається жителям Тернопільської громади. Тому головними статистичними показниками ефективності роботи медичної галузі $€$ рейтингові показники, аналіз яких показує стабільну позитивну ситуацію за всіма параметрами. Особливо потрібно відзначити стійку тенденцію до збільшення кількості населення приріст населення $+5,1$. Лише за останній рік кількість населення в Тернополі збільшилася майже на 400 осіб (табл. 2) [8, 9]. 


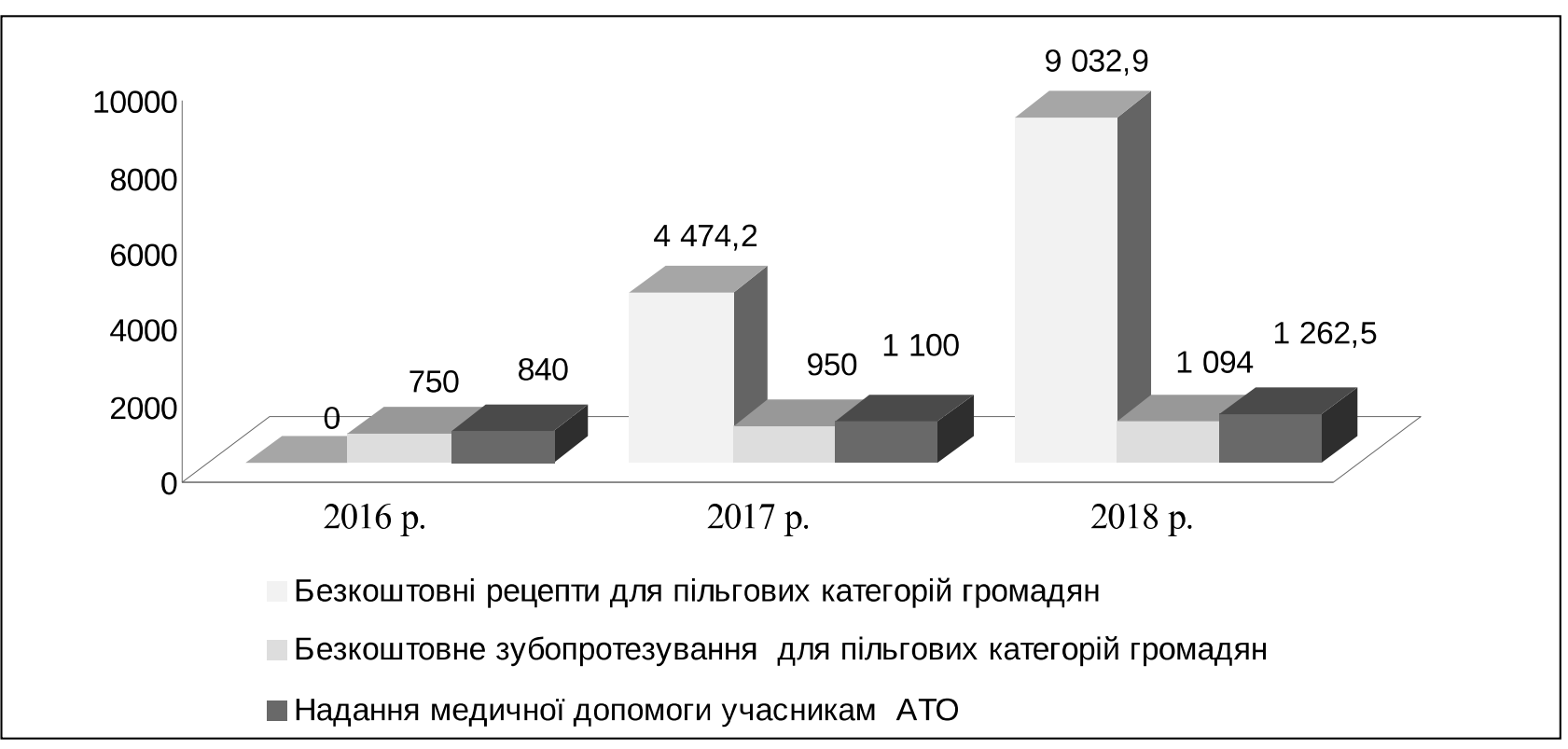

Діаграма 1. Соціальна складова розподілу коштів міського бюджету (тис. грн).

Таблиця 2. Рейтингові показники (на 1000 населення)

\begin{tabular}{|c|c|c|c|c|c|c|c|c|}
\hline \multirow{2}{*}{$\begin{array}{c}\text { Адміністративна } \\
\text { одиниця }\end{array}$} & \multicolumn{2}{|c|}{ Народжуваність } & \multicolumn{2}{|c|}{ Смертність } & \multicolumn{2}{|c|}{ Природний приріст } & \multicolumn{2}{|c|}{ Дитяча смертність } \\
\hline & $2017 \mathrm{p}$. & 2018 p. & 2017 p. & $2018 \mathrm{p}$. & 2017 p. & 2018 p. & 2017 p. & 2018 p. \\
\hline м. Тернопіль & 14,1 & 13,5 & 8,0 & 8,4 & $+6,1$ & $+5,1$ & 7,5 & 5,1 \\
\hline Область & 8,7 & 8,1 & 14,0 & 14,3 & $-5,3$ & $-6,2$ & 8,34 & 6,08 \\
\hline
\end{tabular}

Кілька років тому вперше у Тернополі в місцеву програму медичних гарантій «Здоров'я тернополян» був введений інтегральний показник очікувана тривалість життя, який протягом кількох років зріс на понад 3 роки (для жінок - 78,42, для чоловіків - 68,61), що, в свою чергу, свідчить про правильний вектор розвитку галузі (діагр. 2).

Необхідно відзначити, що галузь охорони здоров'я-пріоритет у роботі Тернопільської міської ради. Тому першочергова ціль рефрормування системи охорони здоров'я міста - зробити перебування жителів громади в лікарнях більш комфортним. 3 цією метою в усіх лікувальних закладах оновлено меблі, туалети, вперше за тривалий час придбано м'який інвентар, білизну, ковдри, матраци, подушки. Планомірно виконуються ремонти та оновлення структурних підрозділів.

Підтримання на належному рівні закладів охорони здоров'я вимагає не тільки проведення сучасних ремонтів і реконструкцій, але й придбання високотехнологічного обладнання. Цим питанням Тернопільська міська рада займається системно і планомірно - оновлений парк рентген-апаратури, діагностичних та лікувальних приладів. Усього в 2018 р. на вищевказані витрати направлено 23 млн 783,1 тис. грн (діагр. 3).

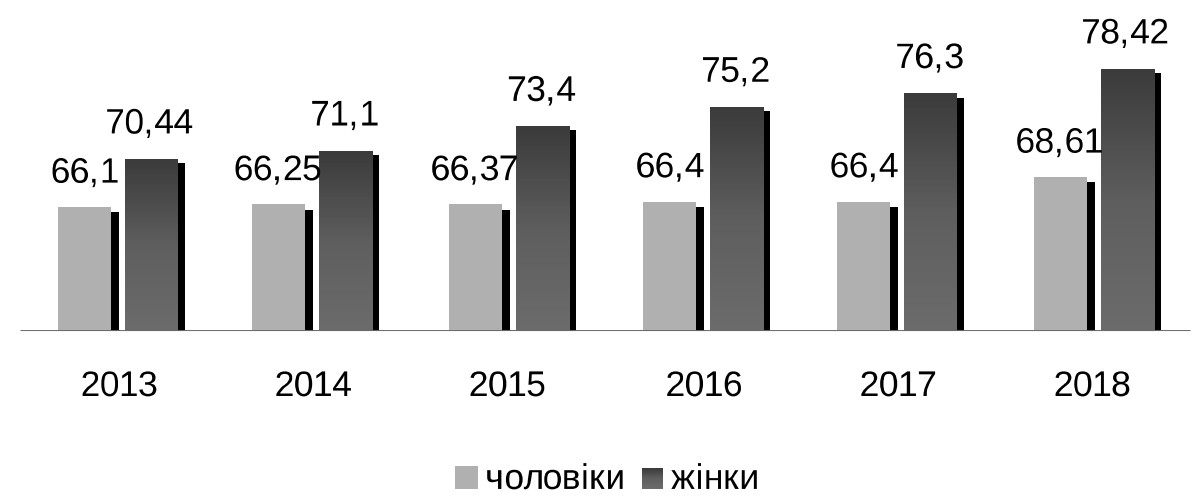

Діаграма 2. Середня тривалість життя тернополян (роки). 


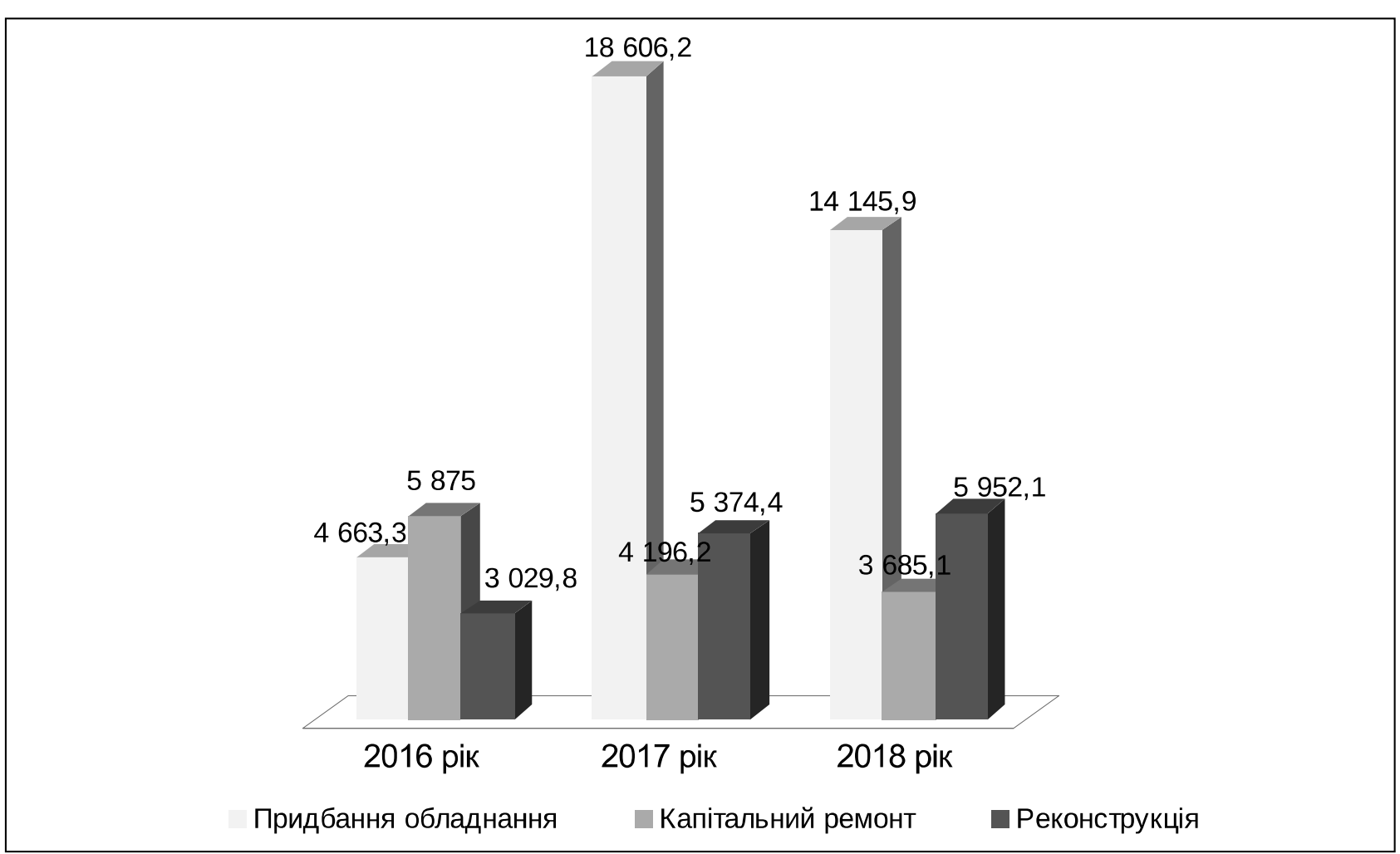

Діаграма 3. Освоєння капітальних видатків, покращення матеріально-технічної бази (тис. грн).

3 метою усунення хронічного недофрінансування, дисбалансу між потребами та надходженнями виникла необхідність пошуку оптимальної моделі фрункціонування галузі охорони здоров'я. Тому в І півріччі 2018 р. громадською організацією «Громадська спілка з реорганізації системи охорони здоров'я України» був проведений незалежний аудит галузі та разом із відділом охорони здоров'я та медичного забезпечення Тернопільської міської ради визначений вектор розвитку медицини громади на найближчі роки 3 урахуванням децентралізації та створення Тернопільської об'єднаної територіальної громади.

Результатом аудита стала модель модернізації охорони здоров'я міста, яка полягає у визначенні пріоритетних завдань та спеціалізації закладів охорони здоров'я, ліквідації дублювання функцій та неефективного використання ресурсів [4]. При цьому було проведено повну дерегуляцію діяльності комунальних підприємств, отримано повну господарську та фрінансову незалежність. Як результат цих змін - укладання на поточний рік угоди між міською радою та КНП, так зване «муніципальне замовлення», де з міського бюджету фрінансуються пріоритетні завдання, делеговані закладам охорони здоров'я міською радою.

При фрормуванні бюджету охорони здоров'я тернопільської громади на 2019 р. за рахунок дофрінансування з міського бюджету повністю закладено кошти на заробітну плату. Таким чином, вперше за багато років немає десріциту коштів на заробітну плату. Всі ці зміни увійшли в нову Програму «Здоров'я громади на 2019-2021 роки», яка була прийнята сесією міської ради в кінці 2018 р. [3].

\section{Висновки}

Ми спостерігаємо чітку позитивну тенденцію фрінансування медичної галузі міста, в якій значну роль відіграють кошти місцевого бюджету. Завдяки ефективному розподілу цих коштів у 2018 р. вдалось уникнути заборгованості із заробітної плати працівникам закладів охорони здоров'я, модернізувати медичні установи та оснастити їх сучасним обладнанням. Про ефективну діяльність галузі охорони здоров'я міста Тернополя свідчить також підвищення тривалості життя тернополян, позитивний природний приріст. Консолідація зусиль місцевої влади за умов децентралізації та органів управління центрального рівня $\epsilon$ беззаперечним ключем до успіху в ресрормуванні медичної галузі міста Тернополя.

Перспективи подальших досліджень. Подальше вивчення ефрективних механізмів муніципального замовлення медичної галузі за сучасних умов децентралізації стане ефрективним важелем впровадження реформи системи охорони здоров'я в місті Тернополі, оскільки державне фрінансування не забезпечує функціонування системи навіть на 30 \%. Тому значне фрінансове навантаження покладено на місцевий рівень, а саме, на Тернопільську міську раду та безпосередньо на самі медичні заклади в статусі комунальних некомерційних підприємств. 


\section{Список літератури}

1. Звіт про роботу відділу охорони здоров'я та медичного забезпечення [Електронний ресурс] : рішення виконавчого комітету Тернопільської міської ради від 28.11.2018 р. № 911. - Режим доступу : https://rada.te.ua/vikonavchiy-komitet/ rishennya-vikonavchogo-komitetu/24920.html.

2. Про бюджет міста Тернополя на 2018 рік [Електронний ресурс] : рішення сесії Тернопільської міської ради від 15.12.17 № 7/21/42. - Режим доступу : https://rada.te.ua/byudget-ternopolya/rishennya-ternopilskoi-miskoi-radi-z-pitanbyudgetu/.

3. Про затвердження дорожньої карти реорганізації галузі охорони здоров'я міста на 2018-2020 рр. [Електронний ресурс] : рішення сесії Тернопільської міської ради від 19.12.19 № 7/31/13. - Режим доступу : https://rada.te.ua/ sesiya/rishennya-sesii/22273.html.

4. Про затвердження комплексної програми «Здоров'я тернополян» на 2019-2021 роки [Електронний ресурс] : рішення сесії Тернопільської міської ради від 19.12.19 № 7/31/13. - Режим доступу : https://rada.te.ua/ekonomika/ galuzevi-programi/galuzevi-programi-chinni-u-2019-rotsi/26469.html.

5. Про схвалення концепції реформи фрінансування системи охорони здоров'я [Електронний ресурс] : розпорядження КМУ від 30.11.2016 р. №1013-p. - Режим доступу : https://www.kmu.gov.ua/ua/npas/249626689.

6. Про схвалення Концепції рефрормування місцевого самоврядування та територіальної організації влади : розпорядження КМУ від 01.04.2014 р. № 333-р. - Урядовий кур'єр. - 2014. - 11 квітня.

7. Про утворення Національної служби здоров'я України [Електронний ресурс] : Постанова КМУ від 27.12.2017 р. № 1101. - Режим доступу : https://zakon.rada.gov.ua/laws/show/1101-2017-\%D0\%BF.

8. Статистичний довідник інорормаційно-аналітичного центру медичної статистики відділу охорони здоров'я та медичного забезпечення Тернопільської міської ради. - 2017. - С. 6-28.

9. Статистичний довідник інформаційно-аналітичного центру медичної статистики відділу охорони здоров'я та медичного забезпечення Тернопільської міської ради. - 2018. - С. 8-29.

10. Тропіна В. Б. Бюджетне забезпечення соціальної функції держави в Україні / В. Б. Тропіна // Фінанси України. 2008. - № 5. - C. 15-31.

\section{References}

1. Rishennia vykonavchoho komitetu Ternopilskoi miskoi rady vid 28.11.2018 roku №911 "Zvit pro robotu viddilu okhorony zdorovia ta medychnoho zabezpechennia" [Decision of the Executive Committee of Ternopil City Council dated 28.11.2018, No. 911 "Report on the work of the Department of Health and Medical Care"]. Retrieved from: https://rada.te.ua/vikonavchiykomitet/rishennya-vikonavchogo-komitetu/24920.html [in Ukrainian].

2. Rishennia sesii Ternopilskoi miskoi rady vid 15.12.17 №7/21/42 "Pro biudzhet mista Ternopolia na 2018 rik" [Decision of the session of the Ternopil city council dated December 15, 17, No. 7 / 21/42 "On the budget of the city of Ternopil in 2018"]. Retrieved from: https://rada.te.ua/byudget-ternopolya/rishennya-ternopilskoi-miskoi-radi-z-pitan-byudgetu/ [in Ukrainian]. 3. Rishennia sesii Ternopilskoi miskoi rady vid 19.12.19 №7/31/13 "Pro zatverdzhennia dorozhnoi karty reorhanizatsii haluzi okhorony zdorovia mista na 2018-2020rr." [Decision of the session of the Ternopil City Council dated December 19, 19, No. 7 / 31/13 "On approval of the road map for the reorganization of the city healthcare industry for 2018-2020"]. Retrieved from: https://rada.te.ua/sesiya/rishennya-sesii/22273.html [in Ukrainian].

4. Rishennia sesii Ternopilskoi miskoi rady vid 19.12.19 №7/31/13 "Pro zatverdzhennia komleksnoi prohramy "Zdorovia ternopolian" na 2019-2021 roky" [Decision of the session of the Ternopil City Council of 19.12.19 No. 7/31/13 "On approval of the complex program" Health of Ternopil "in 2019-2021"]. Retrieved from: https://rada.te.ua/ekonomika/galuzeviprogrami/galuzevi-programi-chinni-u-2019-rotsi/26469.html [in Ukrainian].

5. Rozporiadzhennia KMU vid 30.11.2016 roku №1013-r "Pro skhvalennia kontseptsii reformy finansuvannia systemy okhorony zdorovia" [Resolution of the CMU dated November 30, 2016 No. 1013-p "On approval of the concept of health care financing reform"]. Retrieved from: https://www.kmu.gov.ua/ua/npas/249626689 [in Ukrainian].

6. Rozporiadzhennia KMU vid 01.04.2014 roku №333-r "Pro skhvalennia Kontseptsii reformuvannia mistsevoho samovriaduvannia ta terytorialnoi orhanizatsii vlady" [Resolution of the Cabinet of Ministers of Ukraine dated April 1, 2014, No. 333-p "On Approval of the Concept of Reforming Local Self-Government and Territorial Organization of Power"]. Uriadovyi kurier - Government Courier, 67 [in Ukrainian].

7. Postanova KMU vid 27.12.2017 roku №1101 "Pro utvorennia Natsionalnoi sluzhby zdorovia Ukrainy" [Resolution of the CMU dated 27.12.2017 No. 1101 "On the Establishment of the National Health Service of Ukraine"]. Retrieved from: https:// zakon.rada.gov.ua/laws/show/1101-2017-\%D0\%BF [in Ukrainian].

8. (2017). Statystychnyi dovidnyk informatsiino-analitychnoho tsentru medychnoi statystyky viddilu okhorony zdorovia ta medychnoho zabezpechennia Ternopilskoi miskoi rady [Statistical reference book of the information-analytical center of medical statistics of the department of health care and medical care of Ternopil city council]. [in Ukrainian].

9. (2018). Statystychnyi dovidnyk informatsiino-analitychnoho tsentru medychnoi statystyky viddilu okhorony zdorovia ta medychnoho zabezpechennia Ternopilskoi miskoi rady [Statistical reference book of the information-analytical center of medical statistics of the department of health care and medical care of Ternopil city council]. [in Ukrainian].

10. Tropina, V.B. (2008). Biudzhetne zabezpechennia sotsialnoi funktsii derzhavy v Ukraini [Budget support for the social function of the state in Ukraine]. Finansy Ukrainy - Finance of Ukraine, 5, 15-31 [in Ukrainian]. 
МУНИЦИПАЛЬНЫЙ ЗАКАЗ КАК МЕХАНИЗМ РЕФОРМИРОВАНИЯ ЗДРАВООХРАНЕНИЯ ГОРОДА ТЕРНОПОЛЯ В УСЛОВИЯХ ДЕЦЕНТРАЛИЗАЦИИ

Т. И. Пискливец ${ }^{1}$, А. Г. Шульгай ${ }^{1}$, Р. Д. Левчук ${ }^{1,2}$, А. С. Сатурская ${ }^{1}$

1ГВУЗ «Тернопольский государственный медицинский университет имени И. Я. Горбачевского МЗ Украины», г. Тернополь, Украина

${ }^{2}$ Тернопольский городской совет, г. Тернополь, Украина

Цель: рассмотреть механизм муниципального заказа медицинской отрасли города Тернополя в условиях децентрализации и реформирования системы здравоохранения.

Материалы и методы. Материалами исследования являются принципы фринансирования системы здравоохранения города Тернополя и работа местных медицинских учреждений, методами - описание, анализ, синтез, обобщение, графический дизайн.

Результаты. В последние годы в условиях децентрализации на местные власти возложена важная задача - создание максимальных возможностей предоставлять качественные и доступные услуги, не увеличивая при этом налоговой нагрузки на людей. Ежегодно бюджет медицинской отрасли города Тернополя сталкивается с проблемой недофинансирования из государственного бюджета. В 2018 г. дефицит бюджета на заработную плату составлял почти 50 млн грн. Поэтому Тернопольский городской совет собственными средствами компенсирует эту разницу. Так, в 2018 г. финансирование из городского бюджета составляет 65 млн 377 тыс. грн или 24,3 \% всего финансирования медицины. В 2019 г. в отрасль здравоохранения города заложено 84,6 млн грн или 33,6 \% от общего бюджета. Также установлено, что бюджет медицины в 2018 г. - социально направленный. Основной акцент сделан на выдачу бесплатных рецептов, зубопротезирование льготных категорий граждан, медицинскую помощь участникам ATO, чернобыльцам. Здравоохранение - приоритет деятельности Тернопольского городского совета. Поэтому средства из городского бюджета выделяют не только на социальный состав, но и на проведение капитальных ремонтов, реконструкций, закупки нового оборудования. Также благодаря фринансовым средствам, выделенным из городского бюджета, впервые за много лет нет десицита средств на заработную плату.

Выводы. Наблюдается четкая положительная тенденция фринансирования медицинской отрасли города из городского бюджета, на что указывают отсутствие задолженности по заработной плате работникам учреждений здравоохранения, модернизация медицинских учреждений и оснащение их современным оборудованием, повышение продолжительности жизни тернополян, положительный естественный прирост.

КЛЮЧЕВЫЕ СЛОВА: медицина; здоровье; финансирование; бюджет; децентрализация.

\section{MUNICIPAL ORGANIZATION AS A MECHANISM OF HEALTH CARE REFORM OF TERNOPIL IN TERMS OF DECENTRALIZATION \\ T. I. Pysklyvets ${ }^{1}$, A. H. Shulhai ${ }^{1}$, R. D. Levchuk ${ }^{1,2}$, H. I. Saturska ${ }^{1}$}

${ }^{1}$ I. Horbachevsky Ternopil State Medical University, Ternopil, Ukraine

${ }^{2}$ Ternopil Town Council, Ternopil, Ukraine

Purpose: to consider the mechanism of the municipal order of the medical industry of the Ternopil city in conditions of decentralization and reformation of the health care system.

Materials and Methods. The principles of financing the health care system of the Ternopil city and the work of local medical institutions. Research methods are description, analysis, synthesis, generalization, graphic design.

Results. Over the past few years, in a context of decentralization, the important task of local authorities is to create maximum opportunities to provide high-quality and affordable services without increasing the tax burden on people. Every year, the budget of the medical industry of the Ternopil city faces the problem of underfunding from the state budget. Only in 2018 the deficit of the budget on wages was almost UAH 50 million. Therefore, Ternopil city council compensates this difference by its own means. So, in 2018 , the financing of the city budget is 65 million 377 thousand UAH or $24.3 \%$ of the total financing of medicine. In 2019 , the health care sector of the city put up 84.6 million UAH or $33.6 \%$ of the total budget. It is also established that the budget of medicine in $2018-$ socially directed. The main emphasis is on the issue of free recipes, dentistry of privileged categories of citizens, medical assistance to members of the anti-terrorist organization, and Chernobyl victims. Healthcare is the priority of the Ternopil City Council. Therefore, the funds from the city budget are allocated not only to the social structure, but also for capital repairs, reconstruction, procurement of new equipment. Also, due to the funds allocated from the city budget, for the first time in many years there is no shortage of funds for wages.

Conclusions. There is a clear positive tendency to finance the medical industry of the city from the city budget, as evidenced by the lack of salary arrears for health care providers, the modernization of medical facilities and their equipment with modern equipment, life expectancy for Ternopil regions, positive natural growth.

KEY WORDS: medicine; health; financing; budget; decentralization. 


\section{Відомості про авторів:}

Пискливець Тетяна Ігорівна - завідувач поліклініки Комунального некомерційного підприємства «Тернопільська комунальна міська лікарня № 2», магістр, асистент кафедри соціальної медицини, організації та економіки охорони здоров'я з медичною статистикою дВНЗ «Тернопільський державний медичний університет імені І. Я. Горбачевського МОЗ України»; тел.: +38(0352) 26-12-67.

Шульгай Аркадій Гаврилович - проректор з науково-педагогічної роботи, доктор медичних наук, просесор кафредри соціальної медицини, організації та економіки охорони здоров'я з медичною статистикою ДВНЗ «Тернопільський державний медичний університет імені І. Я. Горбачевського МОЗ України»; тел.: +38(0352) 52-72-33.

Левчук Ростислав Дмитрович - кандидат медичних наук, доцент кафедри соціальної медицини, організації та економіки охорони здоров'я з медичною статистикою ДВНЗ «Тернопільський державний медичний університет імені І. Я. Горбачевського МОЗ України», начальник відділу охорони здоров'я та медичного забезпечення Тернопільської міської ради; тел.: +38(0352) 52-56-96.

Сатурська Ганна Степанівна - доктор медичних наук, професор кафедри соціальної медицини, організації та економіки охорони здоров'я з медичною статистикою ДВНЗ «Тернопільський державний медичний університет імені І. Я. Горбачевського МОЗ України»; тел.: +38(0352) 52-72-33. 